\title{
ETHICAL WORK CLIMATE UNTUK MENCIPTAKAN MORAL AWARENESS KARYAWAN PADA KOPERASI BANK PERKREDITAN RAKYAT TRIBAKTI NGANJUK
}

\author{
Siti Sulasmi dan IGM Dwi Widhianto* \\ Departemen Manajemen FE UNAIR; alumni MM UNAIR
}

\begin{abstract}
This study would examined empirically which one of these ethical criteria, namely self-interest, company, interest, efficiency, friendship, team play, social responsibility, personal morality, rules and procedures, and the law or professional code variables as the criterias to create Ethical Work Climate influenced significantly upon moral awareness of the 170 marketing division employee of TRIBAKTI KBPR (Koperasi Bank Perkreditan Rakyat - People Credit Cooperative Bank) in Nganjuk East Java. The result showed that self-interest, company interest, efficiency, friendship, team play, social responsibility, personal morality, rules and procedures, as well as professional code variables simultaneously create significantly employees moral awareness. Individually, rules and procedure, friendship, team play, personal morality, as well as the law or professional code variables were the ethical criterias that significantly arouse moral awareness. While self-interest criteria variable was to some extent significant, it were contrary to moral awareness development of KBPR's employees. The other three Ethical Work Climate variables, namely company interest, efficiency and social responsibility showed no significant effect.
\end{abstract}

Keywords : Ethical Work Climate, Moral Awareness.

\section{Pendahuluan}

Pengelolaan organisasi saat ini menuntut adanya perubahan dari yang tradisional menjadi yang moderen. Moderen artinya tidak saja karena menggunakan teknologi yang baru, tetapi juga dilibatkannya praktek-praktek yang etikal pada tingkatan manajerial maupun operasional, serta pada praktek pemasaran berkenaan dengan sikap organisasi terhadap para pelanggannya.

Dalam aktivitas perusahaan yang kompleks dimungkinkan munculnya perilaku pelanggaran etika karena ada kecenderungan orang lebih pragmatis dalam berbagai macam situasi. Oleh sebab itu dalam kondisi apapun perlu suatu moral awareness (kesadaran moral), agar keputusan yang dibuat sekalipun dalam kondisi yang mendesak tetap bernilai etikal. Hal ini yang mendorong terciptanya kehatihatian pengambilan keputusan pada saat dihadapkan dilema moral. Terdapat 3 alasan mengapa penting untuk meneliti moral awareness dalam pengambilan keputusan bisnis, yaitu pertama, untuk mengetahui penyebab dari berbagai 
macam keadaan yang menciptakan moral awareness. Kedua, dengan mengetahui penyebab terciptanya kesadaran moral, perusahaan mampu menciptakan suatu situasi yang dapat mengembangkan moral awareness dalam bekerja tersebut. Ketiga, prinsip etikal yang hidup dalam organisasi merupakan faktor lingkungan yang mempunyai pengaruh cukup besar untuk membangun moral awareness (Vansandt et al., 2006).

Bagian marketing KBPR TRIBAKTI Nganjuk dihadapkan pada dilema antara tuntutan pekerjaan yang mengharuskan terpenuhinya target dan variasi keadaan di pasar. Variasi pasar yang dihadapi bagian marketing tersebut memungkinkan terjadi anomali dalam pengambilan keputusan. Bagian marketing pada KBPR ini dihadapkan pada 2 hal yang bersifat saling meniadakan (trade off). Jika menerapkan semua etika aturan yang berlaku dalam mendapatkan nasabah dengan sangat menekankan perilaku moral, diperkirakan akan lebih sulit untuk memenuhi target. Hasil wawancara dengan pihak manajemen KBPR TRIBAKTI Nganjuk menunjukkan ada kemungkinan tantangan bagi kesadaran moral karyawan bagian marketing. Banyak hal yang memungkinan pelanggaran moral terjadi pada KBPR ini misalnya kemungkinan terjadinya pelanggaran wilayah, pagu kredit, reka jaminan, reka cicilan dan lain sebagainya. Berbagai faktor masih mungkin menjadi penyebab tantangan bagi moralitas karyawan, namun manajemen menyatakan tetap penting adanya tuntutan target yang tinggi, serta iklim kerja etikal, sementara itu kepentingan karyawan untuk memenuhi target tersebut sangat berpotensi untuk menurunkan perilaku moral karyawan dalam bekerja. Selama ini meskipun perusahaan memberikan target yang tinggi, target alokasi kredit tetap tercapai.

Faktor lingkungan organisasional adalah faktor yang menentukan iklim kerja yang etikal. Tidak dapat dipungkiri bahwa iklim etikal yang cenderung individualistik, akan mendorong iklim etikal perusahaan juga individualistik. Secara teoritik faktor lingkungan organisasional dapat dijabarkan dalam sistem etikal yang terbentuk matriks antara kriteria etikal (lihat Tabel 1.), seperti kriteria etikal egoism (memaksimasikan kepentingan diri), kriteria benevolence (memaksimasikan kepentingan bersama) atau kriteria principle (mengikuti kewajiban, aturan, hukum, atau standar, norma umum atau universal), dengan loci of analysis, pada tingkatan individual (individual), pada tingkatan organisasional (local), dan tingkatan kosmopolitan (cosmopolitan). Ketiga standar etikal yang terdiri dari egoism, benevolence dan principle sejalan dengan kategori level moral kognitif menurut Kohlberg (Fisher \& Lovell, 2003 : 174-176). Konsep tingkatan perkembangan moral itu terbagi dalam 3 tingkatan moral, yakni level pra-konvensional yang lebih menekankan praktek etikal untuk melindungi diri, level konvensional yang lebih menekankan kepentingan bersama, dan level post konvensional yang lebih menekankan kepentingan umum. Derajat dari ketiga standar etika yang dianut dalam organisasi yang terdiri dari egoism, benevolence dan principle, akan menciptakan iklim kerja etikal yang hidup dalam organisasi tersebut. Pada tingkat 
individual, maka berdasar ketiga kriteria itu muncul tipe iklim etikal self-interest (interes pada kepentingan diri sendiri), friendship (persahabatan) dan personal morality (moralitas pribadi). Pada lingkup organisasional, ketiga kriteria itu memunculkan tipe iklim etikal dalam bentuk company interest (interes terhadap kepentingan perusahaan), team play (kerja tim) dan rules and procedures (aturan dan prosedur). Sedangkan dalam lingkup umum kemasyarakatan, tipe iklim itu muncul dalam bentuk efficiency (efisiensi), social responsibility (tanggung jawab sosial) dan the law or professional code (hukum atau etika profesional). Dalam setiap organisasi akan berkembang tipe-tipe tertentu yang menentukan iklim kerja etikal mana yang hidup dalam organisasi tersebut.

Tabel 1

Theoretical ethical climates types

\begin{tabular}{lccc}
\hline \multirow{2}{*}{ Criterion } & & \multicolumn{2}{c}{ Locus } \\
\cline { 2 - 4 } & Individual & Local & Cosmopolitan \\
\hline Egoism & Self -interest & Company interest & Efficiency \\
Benevolence & Friendship & Team play & Social responsibility \\
Principle & Personal & Rules and Procedures & The Law or Profesional Code \\
& morality & & \\
\hline
\end{tabular}

Sumber: Victor and Cullen, (1987:56) dikutip oleh VanSandt et al., (2006)

Dalam penelitian ini hendak diteliti secara empirik Ethical Work Climate (EWC), yang berupa kriteria etika yang dikategorikan oleh Victor dan Cullen (1987) dalam Vansandt et al. (2006), yang terdiri dari kriteria etika self interest, company interest, efficiency, friendship, team play, social responsibility, personal morality, rules and procedures dan the law or professional code manakah yang hidup dan berperan menciptakan moral awareness yang dimiliki oleh anggota dalam sebuah organisasi.

Dari latar belakang masalah di atas dapat dirumuskan masalah yang dihadapi adalah sebagai berikut:

1. Apakah seluruh variabel yang membentuk iklim kerja etikal yang terdiri dari selfinterest, company interest, efficiency, friendship, team play, social responsibility, personal morality, rules and procedures, the law or professional code berpengaruh signifikan terhadap moral awareness karyawan KBPR TRIBAKTI Nganjuk?

2. Apakah secara individual seluruh variabel yang membentuk iklim kerja etikal itu yang terdiri dari self-interest, company interest, efficiency, friendship, team play, social responsibility, personal morality, rules and procedures, the law or professional code juga berpengaruh terhadap moral awareness karyawan KBPR TRIBAKTI Nganjuk?

3. Manakah dari beragam tipe EWC itu yang membentuk moral awareness karyawan KBPR Tribakti Nganjuk? 


\section{Landasan Teori}

Iklim Organisasi

Steers (1985:120) menyatakan bahwa : "konsep iklim pada dasarnya merupakan persepsi tentang sifat atau karakteristik yang ada pada organisasi yang dihasilkan dari tindakan sadar atau tidak sadar oleh organisasi dan mempengaruhi perilaku". Definisi ini mengandung pengertian tentang persepsi, dimana iklim suatu organisasi tertentu merupakan sesuatu yang dipercaya ada oleh karyawannya dan akan menjadi faktor-faktor yang menentukan perilaku karyawan. Hal ini sejalan dengan yang dinyatakan oleh Jones dan Ryan (1998) dalam VanSandt et al. (2006) bahwa iklim organisasi berpengaruh secara signifikan terhadap persepsi seseorang dan perilakunya.

Iklim Kerja Etikal (Ethical Work Climate)

Victor \& Cullen, (1987: 51) dalam VanSandt et al.(2006) mendefinisikan bahwa : "Ethical work climate is the shared perceptions of what is ethically correct behavior and how ethical issues should be handled within an organization" Ethical Work Climate (EWC) merupakan bagian dari persepsi yang mempengaruhi pemikiran para anggota organisasi mengenai bagaimana harus berperilaku etikal yang benar dan bagaimana seharusnya menangani isu-isu etikal. Lebih lanjut Victor \& Cullen, (1987: 51) dikutip oleh VanSandt et al. (2006) menyatakan bahwa : "It should be noted at the outset that EWC was not conceived as a normative construct for measuring how ethical a given organization was; rather it was developed as a descriptive indicator of the prevailing mode of ethical thought within an organization". Sekalipun Ethical Work Climate dinyatakan bukan suatu konstruk normatif untuk mengukur bagaimana etika yang berlangsung dalam suatu organisasi, tetapi dapat digunakan untuk menegakkan suatu indikator pemikiran etikal dalam suatu organisasi.

Pertimbangan atas situasi-situasi etikal dengan memperhatikan ruang lingkup etika, biasanya memerlukan dua dimensi fokus pengamatan (Rachels, 1989, 1999; Solomon, 1992), yaitu:

1. Yang pertama menyangkut kriteria etika yang digunakan yang menyangkut masalah hasilnya, prinsip-prinsip yang berkembang, atau aturan lain untuk membuat keputusan.

2. Dimensi ke dua yang disebut sebagai locus of analysis menjelaskan tentang siapa atau apa yang dipengaruhi oleh kejadian dengan cara yang relevan secara etikal. Lingkupnya dapat bersifat individual (self), organisasi, atau masyarakat. 
Dalam konsep teoritikal yang dikembangkan kemudian oleh VanSandt (2006) dinyatakan bahwa arti dari kedua dimensi tersebut disebut sebagai criteria dan locus of analysis. Criteria yang dikembangkan melibatkan unsur perolehan dan perlindungan diri, kriteria kebaikan, dan kriteria aturan untuk pengambilan keputusan. Sedangkan dimensi kedua disebut sebagai locus of analysis yang menjelaskan apa atau siapa yang dipengaruhi oleh kejadian dengan cara yang etikal. Hal itu dapat terjadi pada tingkat individual, kelompok ataupun masyarakat umum.

Tipe-Tipe Iklim Kerja Etikal (Ethical Work Climates Types)

Victor and Cullen (1987:56) dikutip oleh VanSandt et al.(2006) mengkombinasikan dua dimensi dari moral reasoning (ethical criteria and locus of analysis) ke dalam bentuk tipologi teoritik yang membentuk ethical work climate, yang telah disajikan pada Tabel 1.

\section{Ethical Criteria}

Dalam banyak hal moral philosophy dapat dikategorikan dalam dua golongan utama, yaitu teleological dan deontological. Teleological moral philosophies merupakan filosofi yang menaruh perhatian utama pada dampak atau konsekuensi dari sebuah situasi etika. Sementara itu deontological philosophies tidak hanya semata-mata perhatian pada konsekuensi, namun lebih pada prinsip-prinsip dan situasi yang lebih menekankan kewajiban.Teleological moral philosophies terbagi dalam dua kelas yang dinamakan sebagai "the moral agent primary consideration (egoistic) and utilitarian or benevolent" (Rachels, 1989, 1999; Brandt, 1995, dalam Vansandt et al. (2006).

Victor and Cullen $(1987,1988)$ dikutip oleh VanSandt et al.(2006) mengunakan tiga klasifikasi moral philosophy untuk mendesain dimensi criteria dari EWC. Deskripsi dari pelabelan criteria adalah :

1. Egoism - memaksimalkan kepentingan pribadi

2. Benevolence - memaksimalkan kepentingan bersama

3. Principle - ketaatan pada tugas, peraturan, hukum atau standar yang berlaku

Locus of Analysis

Dimensi kedua adalah pertimbangan dari apa atau siapa yang dilibatkan dalam analisis. Pada tingkatan pertimbangan dapat dijabarkan mulai dari yang paling bawah, yaitu local individual, the local organization, serta cosmopolitan. Menurut Merton (1957) dikutip oleh VanSandt et al.(2006) dinyatakan bahwa peran kerja pada organisasi dan identifikasi perbedaan referensi kelompok kerja berpengaruh 
pada perilaku seseorang dan sikap dalam organisasi. Seseorang kemudian akan mengelola informasi untuk membedakan antara peran local dan cosmopolitan. Pada peran lokal referensi kelompok berpengaruh dalam organisasi, sementara itu peran kosmopolitan adalah didefinisikan sebagai peran di luar organisasi.

a. Locus of analysis tingkatan individual

Self interest adalah salah satu tipe kriteria etika yang mementingkan proteksi diri yang disebut sebagai kriteria etika egoism dalam bisnis. Friendship adalah ranah atau lingkup kepentingan individual yang menggunakan kriteria etika benevolence (kebajikan atau kebaikan) dalam hal pengutamaan sikap persahabatan. Personal morality adalah moralitas individual yang menunjukkan etika yang memegang teguh pada principle (akidah) yang bersifat perorangan.

b. Locus of analysis tingkatan local

Pada kolom kedua disajikan tentang kaitan antara iklim etikal pada lingkup organisasional yang dihubungkan dengan kriteria etika egoism, benevolence (kebajikan) dan principle (prinsip). Dikaitkan dengan kriteria etika egoism dalam lingkup intern organisasional ditunjukkan oleh perilaku orang-orang dalam organisasi yang mengutamakan company interest (kepentingan perusahaan). Sementara itu dikaitkan dengan kriteria etika benevolence dalam lingkup intern organisasional ditunjukkan perilaku team play (kerjasama orang-orang dalam organisasi dalam bergaul dengan kelompok atau tim). Selanjutnya dikaitkan dengan kriteria principle dalam lingkup intern organisasional ditunjukkan perilaku orang-orang dalam organisasi yang patuh dan mengikuti aturan dan prosedur yang akan menjadi pedoman bagi anggota organisasi (rules and procedures).

\section{c. Locus of analysis tingkatan kosmopolitan}

Pada kolom ketiga pada Tabel 1. disajikan tentang kaitan antara ranah atau lingkup cosmopolitan yang dihubungkan dengan kriteria etika egoism, benevolence (kebajikan) dan principle. Cosmopolitan dikaitkan dengan kriteria etika egoism, ditunjukkan perilaku orang-orang dalam organisasi yang mengutamakan efficiency (etika menjalankan pekerjaan dengan benar). Lingkup cosmopolitan dikaitkan dengan kriteria etika benevolence, ditunjukkan perilaku orang-orang dalam organisasi yang mengutamakan social responsibility (tanggung jawab sosial). Lingkup cosmopolitan dikaitkan dengan kriteria etika principle, ditunjukkan perilaku orang-orang dalam organisasi yang mematuhi the law or professional code (hukum atau kode etik profesional yang umum berlaku). 


\section{Moral Awareness}

Moral awareness didefinisikan sebagai derajat dimana seseorang mengenali aspekaspek situasi yang dapat dikategorikan sebagai moral yang salah dan merugikan bagi orang lain, sekelompok orang, atau masyarakat lebih luas (VanSandt et al. 2006). Moral awareness di sini didefinisikan dalam bentuk derajat, bukan sebagai sesuatu yang ada atau tiada. Definisi tersebut merujuk pada definisi dari Blum (1991) yang membahas moral sebagai suatu proses.

\section{Hubungan Ethical Work Climate Dengan Moral Awareness}

Wimbush and Shepard (1994) menyatakan bahwa studi yang dilakukan menyediakan bukti-bukti substansial yang menunjukkan hubungan langsung antara iklim organisasi dengan perilaku. Dengan demikian dinyatakannya bahwa perilaku ditentukan oleh pengaruh lingkungan dan hal lain yang menciptakan suatu iklim tertentu. Sementara itu Blum (1991) dan Rest (1994) menyatakan bahwa moral awareness sangat dibutuhkan dan merupakan bagian integral dari moral behavior. Hasil penelitian Victor and Cullen (1987: 55) dikutip oleh VanSandt et al. (2006) menghasilkan temuan: "The dominant type of ethical climate in an organization may influence the types of ethical conflicts considered, ........". Disampaikan bahwa tipe yang dominan dari ethical climate dalam organisasi bisa jadi mempengaruhi tipe konflik yang terjadi.

Lebih jauh Cullen, Victor, and Stephens (1989: 51) menyatakan, ethical climate perusahaan membantu menentukan isu-isu yang penting dan muncul pada anggota organisasi yang berhubungan dengan etika. Dalam iklim etikal tertentu, timbul suatu interaksi antar manusia atau diantara anggotanya dengan cara tertentu pula. Dengan cara itu akan terpelihara dan tumbuh kembang suatu kesadaran moral akibat dari interaksi itu. Maka itu sangat dimungkinkan bahwa lingkungan etikal dapat berpengaruh terhadap tingkat kesadaran moral (moral awareness) seseorang. 
Kerangka Konseptual

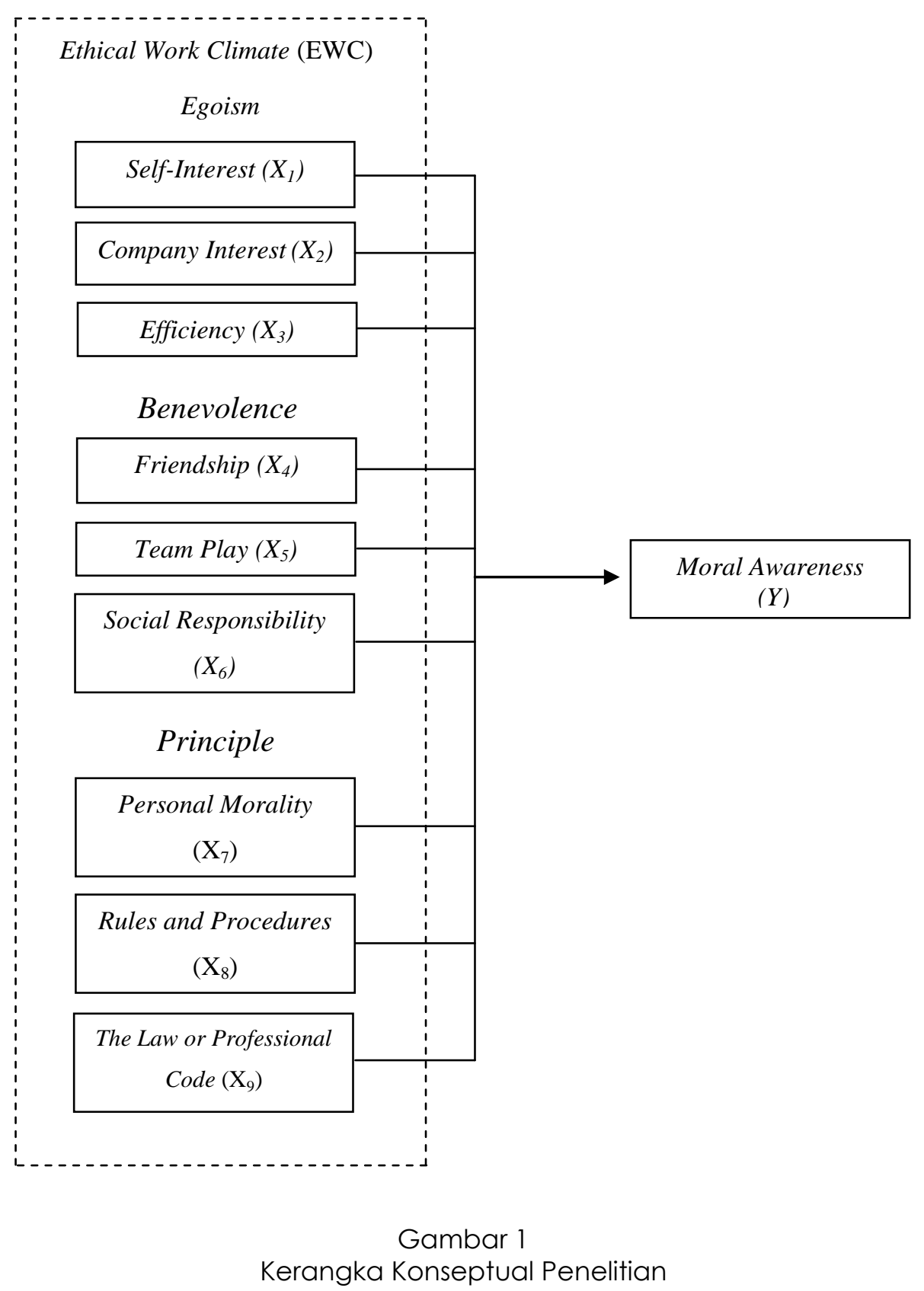


Hipotesis

Hipotesis 1. Variabel self-interest, company interest, efficiency, friendship, team play, social responsibility, personal morality, rules and procedures, the law or professional code adalah variabel kriteria etika yang membangkitkan moral awareness karyawan KBPR TRIBAKTI Nganjuk.

Hipotesis 2. Variabel self-interest, company interest, efficiency, friendship, team play, social responsibility, personal morality, rules and procedures, the law or professional code mempunyai pengaruh yang signifikan secara individual terhadap moral awareness karyawan KBPR TRIBAKTI Nganjuk.

\section{Metode Penelitian}

Pengukuran Ethical Work Climate dilakukan dengan menggunakan kuesioner yang diadaptasi dari penelitian oleh VanSandt (2001), dengan menggunakan skala Likert. Pengukuran moral awareness dilakukan dengan menggunakan Defining Issue Test yang situasinya disesuaikan dengan isu yang ada di KBPR Tribakti. Sampel yang digunakan adalah 170 dari 180 orang karyawan divisi pemasaran yang bertugas langsung menghadapi nasabah yang bertugas sebagai sebagai account excutive.

Untuk melaksanakan penelitian ini digunakan teknik Analisis Regresi Berganda diolah dalam program SPSS. Seluruh uji asumsi klasik digunakan, selain itu juga dilakukan uji validitas dan reliabilitas alat ukur.

\section{Hasil dan Pembahasan}

Hasil penelitian menunjukkan bahwa $74,1 \%$ perubahan variabel terikat (moral awareness karyawan bagian marketing KBPR TRIBAKTI) mampu dijelaskan oleh variabel-variabel bebas yang dimasukkan dalam model (self-interest, company interest, efficiency, friendship, team play, social responsibility, personal morality, rules and procedures dan the law or professional code) secara bersama-sama, sedangkan sisanya $25,9 \%$ dijelaskan oleh variabel lain yang tidak dimasukkan dalam model.

Variabel dengan nilai beta tertinggi adalah rules and procedures ( $\left.X_{8}\right)$ sebesar 0,299 merupakan variabel dengan pengaruh dominan yang mempengaruhi moral awareness. KBPR TRIBAKTI adalah perusahaan yang bergerak dalam bisnis perbankan dengan modal utama adalah kepercayaan masyarakat. Untuk membangun kepercayaan itu perusahaan memiliki tata tertib yang mengikat bagi setiap anggota organisasi termasuk karyawan marketing. Tata tertib tersebut bersifat mengikat dalam artian ada penghargaan jika karyawan berprestasi dan ada sanksi jika karyawan melakukan pelanggaran tata tertib. Menurut hasil wawancara, 
penerapan sanksi atas pelanggaran tata tertib sangat tegas. Hal ini dilakukan untuk menjaga nama baik organisasi dan kepercayaan masyarakat terhadap organisasi.

Berdasarkan hasil pengolahan data, maka hasil uji regresi adalah sebagai berikut :

Tabel 2

Hasil Analisis Regresi

\begin{tabular}{|c|c|c|c|c|c|}
\hline Variabel & $\begin{array}{c}\text { Koefisien } \\
\text { Regresi }\end{array}$ & $\begin{array}{l}\text { Standart } \\
\text { Error }\end{array}$ & $T$ & $\begin{array}{c}\text { Signifik } \\
\text { ansi }\end{array}$ & Beta \\
\hline Self-Interest & $-0,032$ & 0,016 & $-2,015$ & 0,046 & $-0,085$ \\
\hline Company Interest & $-0,003$ & 0,018 & $-0,206$ & 0,837 & $-0,009$ \\
\hline Efficiency & $-0,006$ & 0,020 & $-0,330$ & 0,741 & $-0,014$ \\
\hline Friendship & 0,115 & 0,031 & 3,688 & 0,000 & 0,188 \\
\hline Team Play & 0,152 & 0,031 & 4,917 & 0,000 & 0,261 \\
\hline Social Responsibility & 0,049 & 0,030 & 1,664 & 0,098 & 0,081 \\
\hline Personal Morality & 0,080 & 0,030 & 2,657 & 0,009 & 0,133 \\
\hline Rules and Procedures & 0,208 & 0,037 & 5,660 & 0,000 & 0,299 \\
\hline The Law or & 0,167 & 0,035 & 4,821 & 0,000 & 0,238 \\
\hline \multicolumn{6}{|l|}{ Professional Code } \\
\hline Constan & \multicolumn{2}{|c|}{$=$} & \multicolumn{3}{|c|}{1,050} \\
\hline Adj. $R^{2}$ & \multicolumn{2}{|c|}{$=$} & \multicolumn{3}{|c|}{0,727} \\
\hline$R^{2}$ & \multicolumn{2}{|c|}{$=$} & \multicolumn{3}{|c|}{0,741} \\
\hline Multiple R & \multicolumn{2}{|c|}{$=$} & \multicolumn{3}{|c|}{0,861} \\
\hline F-ratio & \multicolumn{2}{|c|}{$=$} & \multicolumn{3}{|c|}{50,898} \\
\hline Probability & \multicolumn{2}{|c|}{$=$} & \multicolumn{3}{|c|}{0,000} \\
\hline
\end{tabular}

Manajemen KBPR TRIBAKTI membagi tata tertib menjadi 2 bagian utama, yaitu pelayanan dan hukum. Pada aspek pelayanan karyawan dituntut untuk memberikan pelayanan prima bagi nasabah. Manajemen menerapkan konsep pelayanan berupa dimensi kualitas pelayanan (service quality) berupa reliability, tangible, responsiveness, empathy dan assurance. Manajemen terus melakukan evaluasi atas kinerja karyawan bagian pemasaran dengan mendokumentasikan setiap ada keluhan nasabah dan kemudian melanjutkan pada bagian marketing yang bersangkutan. Sistem ini ternyata mampu membuat karyawan memberikan pelayanan yang memuaskan bagi karyawan dan mendorong terciptanya kesadaran moral yang baik.

Pada aspek hukum karyawan tidak diperkenankan melanggar aturan, termasuk melakukan pelanggaran wilayah, rekayasa agunan, pelanggaran wilayah dan lain sebagainya. Sanksi tegas berupa administrasi dan hukum telah dikomunikasikan (disosialisasikan) dengan baik, sehingga karyawan paham akan sanksi yang diterima, jika melakukan pelanggaran. Kondisi yang demikian berdampak pada kehati-hatian karyawan dalam mengambil keputusan, mempertimbangkan aturan yang berlaku serta meningkatkan moral awareness. Hal tersebut didukung oleh ratarata tanggapan responden atas iklim kerja rules and procedures sebesar 3,95. Hal ini 
dapat diartikan bahwa rata-rata responden menyatakan setuju bahwa rules and procedures merupakan iklim kerja etikal pada KBPR Tribakti Nganjuk. Dapat diartikan bahwa iklim etika yang terbentuk di KBPR Tribakti Nganjuk salah satunya ditentukan oleh aturan dan prosedur tertulis yang memiliki implikasi dan sanksi jelas.

Variabel self-interest $\left(X_{1}\right)$ mempunyai pengaruh negatif yang signifikan terhadap moral awareness KBPR TRIBAKTI dan rata-rata hasil regresi sebesar 2,1726. Hal ini menunjukkan bahwa kepentingan secara signifikan merupakan suatu yang dijauhi, artinya self-interest merupakan hal yang secara sadar dihindari, dan secara signifikan pula bertentangan sebagai sumber utama acuan kesadaran moral dari anggota organisasi ini.

Variabel company interest $\left(\mathrm{X}_{2}\right)$ mempunyai pengaruh negatif tidak signifikan terhadap moral awareness KBPR TRIBAKTI. PerilakU karyawan yang mewakili kepentingan perusahaan merupakan hal yang tidak berarti pengaruhnya. Etika yang berkembang dan mempengaruhi kesadaran moral karyawan tidak signifikan mengacu pada kepentingan perusahaan. Pengaruh negatif yang tidak signifikan company interest terhadap moral awareness ini, berdasar wawancara pihak manajemen, adalah disebabkan oleh filosofi yang dianut oleh pemegang saham dalam berbisnis, yaitu win-win solution. Lebih lanjut disampaikan, jika perusahaan menganut win-lose solution, maka perusahaan akan kehilangan nasabah dan dalam jangka panjang kelangsungan hidup perusahaan juga akan terancam. Sementara itu jika lose-win solution juga mengakibatkan kelangsungan hidup perusahaan juga akan berhenti. Oleh karena itu untuk melindungi kepentingan perusahaan dan kepentingan nasabah, maka setiap pemberian kredit selalu diikuti dengan akta kredit yang bersifat mengikat kedua belah pihak. Namun demikian bila terjadi pelanggaran kontrak oleh nasabah maka pihak manajemen akan melindungi kepentingan perusahaan dengan melakukan tindakan sesuai dengan kesepakatan kontrak. Menurut manajemen, dalam kenyataan di lapangan karyawan di lapangan (debt collector) sering kali berlebihan dalam menyelesaikan masalah. Tindakan karyawan dalam melindungi kepentingan perusahaan di lapangan tersebut menyebabkan tindakan yang tidak proporsional, sehingga halhal yang dikonotasikan untuk melindungi kepentingan perusahaan ada kecenderungan kurang disukai oleh rata-rata para karyawan.

Variabel efficiency $\left(X_{3}\right)$ mempunyai pengaruh negatif tidak signifikan terhadap moral awareness KBPR TRIBAKTI. Walaupun tidak signifikan, nilai negatif menunjukkan kurang pentingnya nilai-nilai efisiensi yang sesungguhnya hal itu merupakan faktor kalkulatif yang seharusnya dipertimbangkan dalam bisnis. Nampaknya unsur suasana kalkulatif dalam bekerja kurang menjadi acuan untuk mengembangkan tingkat kesadaran moral, sehingga perilaku moral tidak signifikan pula dilandasi oleh hal-hal demikian. Kondisi pengaruh yang tidak signifikan itu, dari informasi dalam perusahaan mungkin pula disebabkan oleh kategori perusahaan perbankan sebagai regulated firm atau perusahaan yang secara finansial diatur oleh regulasi. 
Sebagai contohnya adalah regulasi tentang CAR, non performing loan dan likuiditas. Perusahaan perbankan tidak diperkenankan menentukan sendiri besaran rasionya, karena ada regulasi yang mengatur yang bertujuan untuk melindungi nasabah. Dengan melakukan efisiensi, berarti ada beberapa aktivitas yang dihilangkan dalam sebuah proses. Jika perusahaan hanya menekankan pada efisiensi maka akan ada tahapan yang hilang yang berarti akan memunculkan potensi risiko di masa mendatang. Efisiensi diakui sebagai suatu yang penting, namun efisiensi yang berlebihan bisa berdampak pada tingginya risiko yang akan muncul. Sebagai contoh non performing loan yang tinggi bisa jadi disebabkan oleh beberapa tahapan kredit yang tidak dijalankan dengan benar, sehingga terlewat dalam checklist. Efisiensi yang berlebihan akan memunculkan risiko, dan biasanya untuk melindungi kepentingan perusahaan risiko tersebut diselesaikan dengan cara yang tidak proporsional dengan kontrak. Kondisi yang demikianlah yang dianalisis menyebabkan efisiensi berhubungan negatif terhadap moral awereness. Namun demikian pengaruh hal ini tidak siginifikan terhadap terbentuknya moral awareness.

Variabel friendship $\left(\mathrm{X}_{4}\right)$ mempunyai pengaruh positif yang signifikan terhadap moral awareness KBPR TRIBAKTI. Koefisien regresi variabel ini adalah positif, berarti iklim kerja etikal KBPR TRIBAKTI yang terbentuk dari friendship, menentukan tingkat moral awareness. Nilai-nilai kebersamaan rupanya menjadi nilai etikal yang menentukan tingkat kesadaran moral. Hal ini menunjukkan bahwa karyawan mengutamakan nilai-nilai kepedulian dengan setiap orang yang ada diperusahaan, perusahaan memperhatikan keputusan yang diambil oleh karyawan, dan karyawan mencari segala sesuatu yang baik bagi orang lain.

Variabel team play $\left(X_{5}\right)$ mempunyai pengaruh positif yang signifikan terhadap moral awareness KBPR TRIBAKTI. Sejalan dengan signifikansi variabel friendship, maka kerjasama tim menjadi suatu nilai yang penting pula dalam perusahaan ini, sehingga mempunyai pengaruh yang bermakna dalam kesadaran moral dari para karyawannya.

Variabel social responsibility $\left(X_{6}\right)$ mempunyai pengaruh positif tidak signifikan terhadap moral awareness KBPR TRIBAKTI. Hasil wawancara dengan pihak manajemen diperoleh bahwa KBPR telah mengalokasikan dana untuk kepentingan customer social responsibility, antara lain untuk zakat fitrah, masing-masing $10 \mathrm{Kg}$ beras dan sembako lain, berupa mie instan dan minyak goreng. Jika dicermati maka realisasi social responsibility tidak menyentuh kepentingan karyawan dan benar-benar untuk kepentingan masyarakat tidak mampu, di luar kejadian yang dirasakan oleh karyawan. Social responsibility yang demikian tidak signifikan pengaruhnya terhadap moral awareness. Ini dapat terjadi bila karyawan memang melihat social responsibility kurang penting bagi mereka secara pribadi. Dari sudut pandangan karyawan aktivitas perusahaan dalam rangka social responsibility itu lebih ditujukan untuk membentuk image atau citra perusahaan di mata masyarakat. 
Variabel personal morality $\left(X_{7}\right)$ mempunyai pengaruh positif yang signifikan terhadap moral awareness KBPR TRIBAKTI. Hal ini menunjukkan bahwa setiap karyawan mempunyai keputusan dan kesadaran dalam dirinya sendiri tentang apa yang benar dan apa yang salah secara pribadi maupun moral, yang menunjukkan tingkat kesadaran moral mereka. Kesadaran moral yang tumbuh dari prinsip moralitas yang dimiliki oleh anggota organisasi secara perorangan merupakan sumber yang kuat mempengaruhi tingkat kesadaran moral mereka.

Variabel the law or professional code $\left(X_{9}\right)$ mempunyai pengaruh positif yang signifikan terhadap moral awareness KBPR TRIBAKTI. Aturan secara profesional mampu mengikat secara signifikan kesadaran moral anggota organisasi ini. Keketatan mengikuti aturan dan prosedur, serta hukum yang berlaku rupanya yang menjadi penentu dan menjadi penegak kesadaran moral pada para anggota organisasi perusahaan ini.

Dari keseluruhan analisis regresi terhadap 9 variabel independen, hasilnya menunjukkan bahwa nilai nilai kelompok seperti friendship dan team play merupakan sumber pengaruh yang membentuk kesadaran moral. Hal yang bersifat individual, seperti usaha yang dilatar belakangi untuk keuntungan sendiri merupakan sumber yang signifikan ditolak sebagai acuan moral. Hal yang juga sangat efektif untuk membangun kesadaran moral adalah peraturan yang ditegakkan dengan konsisten dan hukum yang dijadikan pedoman dalam berperilaku kerja. Moralitas pribadi merupakan pengendali perilaku yang ikut serta memberikan pengaruh pada kesadaran moral. Sumber-sumber yang di luar lingkungan terdekat, seperti kepentingan organisasi serta tanggung jawab sosial organisasi pada pihak eksternal, serta kepentingan rasional organisasi bukan menjadi acuan utama bertumbuhnya kesadaran moral. Nampaknya ini sejalan dengan analisis bahwa dalam tatanan budaya kolektivistik sumber utama perilaku individual pekerja adalah norma yang berkembang pada kelompok di mana seseorang menjadi anggotanya (Sulasmi, 2003). Dalam tatanan budaya kolektivistik, afeksi dan kekuatan kelompok mampu memberikan pengaruh terhadap sikap dan perilaku individual anggota organisasi. Kepentingan individual menjadi hal yang sangat signifikan dijauhi, dan pedoman perilaku dipengaruhi pula oleh kendali diri masing-masing anggotanya dalam bentuk moralitas individual, serta lingkungan yang secara tegas menerapkan hukum dan aturan yang mengikat. Dengan kuatnya pengaruh aturan dan pedoman berperilaku etikal yang kuat menjadi acuan perilaku, maka peran pemimpin yang tegas menjalankan aturan secara etikal menjadi penting. Penting karakter pemimpin yang berintegritas tinggi, sebagai faktor yang mampu berpengaruh terhadap semangat friendship dan team play dalam kelompok Hasil uji regresi yang dilakukan pada penelitian yang dipaparkan dan diuji kembali oleh Sulasmi (2008), menunjukkan bahwa integritas pribadi pemimpin menentukan semangat kerjasama para anggotanya. Pemimpin yang berintegritas tinggi menggambarkan kepemimpinan yang moralistik, dan sekaligus dipacu oleh kelompok yang berjiwa persahabatan dan kebersamaan akan mampu 
mewujudkan kerjasama itu secara riel (Sulasmi, 2008). Dengan integritas yang tinggi, pemimpin akan mampu menunjukkan ketegasan untuk menerapkan aturan, dengan dasar sikap kooperatif pada anggota yang dipimpinnya, sehingga sikap itu melimpah dalam hubungan kerja para anggota kelompok yang dipimpinnya untuk mengembangkan rasa persahabatan dengan kerjasama tim yang baik. Dalam penelitian ini, dihasilkan suatu kombinasi variabel yang membentuk EWC yang berpengaruh terhadap tingkat kesadaran moral, yakni moralitas pribadi, ketegasan penerapan aturan dan pedoman perilaku etikal, yang disertai dengan rasa persahabatan dan kerjasama. Secara berurutan berdasarkan kekuatan pengaruhnya (koefisien beta), pengaruh terbesar terhadap moral awareness karyawan KBPR TRIBAKTI tersebut adalah rules and procedures, team play, the law or professional code, friendship, personal morality, dan self interest (dengan arah yang berlawanan). Untuk pekerjaan pemasaran di KBPR TRIBAKTI ini, variabel kondisi organisasional merupakan hal yang sangat penting berpengaruh terhadap kesadaran moral. Menjadi penting sekali tegaknya aturan dan kontrol prosedur, serta kondisi sosial anggotanya dalam bentuk keakraban. Kepatuhan terhadap hukum dan kode etik profesi merupan acuan pula bagi kesadaran moral, oleh karena itu lemahnya penegakan hukum, pelaksanaan dan kendali terhadap aturan yang berjalan pada KBPR ini akan sangat mungkin menurunkan kesadaran moral tersebut. Dalam penelitian ini belum nampak adanya variabel etos kerja yang diharapkan juga mampu mempengaruhi kesadaran moral itu, sehingga moralitas kerja tidak hanya terbentuk atas aturan dan keakraban, tetapi juga suatu etos kerja yang tinggi. Mengingat bahwa keluhan yang sering terdengar pada kondisi pekerja di Indonesia adalah pada etos kerja, maka perlu disertakan suatu ukuran etos kerja, yang pada akhirnya nanti tidak hanya mempengaruhi kesadaran moral, tetapi juga efek pada tingkat kinerja. Kerja tim tidak hanya diukur dari tingkat kerjasama saja, tetapi termasuk di dalamnya norma untuk mencapai tingkat kinerja yang tinggi. Perlu dilekatkan dalam rancangan model penelitian bahwa keakraban dalam sebuah kelompok bukan hanya tujuan, tetapi di dalamnya perlu dikembangkan kerjasama yang dilandasi oleh etos kerja yang tinggi.

Seharusnya kriteria efisiensi dan keberpihakan pada organisas, serta tanggung jawab sosial perlu menjadi acuan untuk penegakan kesadaran moral. Niat untuk melakukan efisiensi, dan melakukan aktivitas kerja untuk mendukung tujuan organiasi adalah suatu yang bersifat normatif perlu ada. Disamping itu, kerjasama dengan pihak lain, yang diwujudkan dalam bentuk tanggung jawab sosial, semestinya sanggup secara nyata menginspirasi kesadaran moral karyawan. Namun hal semacam itu tidak signifikan terjadi. Keberpihakan pada kelompok kerja dan kepentingan bersama dan dengan kelompok kerjanya lebih mengedepan, oleh sebab itu perusahaan perlu memberikan perhatian khusus terhadap dinamika kerjasama dalam kelompok kerja itu. Menjadi hal yang penting bagi manajemen untuk senantiasa menjaga noma dan aktivitas kerja kelompok dengan kepemimpinan yang memadai, hingga kelompok kerja tidak mudah terjebak pada kekuatan kelompok yang menyimpang dari tujuan kinerja organisasi. 


\section{SIMPULAN}

Berdasarkan analisis dan pembahasan yang telah dilakukan, maka simpulan yang dapat diambil adalah bahwa:

1. Pada penelitian ini, pengutamaan kepentingan pribadi dalam bekerja merupakan hal yang secara signifikan dijauhi dalam berbisnis, sekalipun tidak dapat dipungkiri hasil penelitian menunjukan bahwa secara bersama-sama dengan variabel lain, kepentingan pribadi memberikan pengaruh. Tentunya proteksi diri tetap diperlukan. Bahkan untuk kepentingan perusahaan dan kemasyarakatan rupanya secara nyata bukan menjadi acuan pengembangan kesadaran moral karyawan.

2. Nilai-nilai kelompok seperti friendship dan team play merupakan suasana yang pengaruhnya kuat untuk menentukan tingkat kesadaran moral, demikian juga variabel moralitas pribadi. Pengembangan kesadaran moral dapat dilakukan melalui hubungan persahabatan dan kerja sama, disertai dengan moralitas pribadi yang turut berperan nyata.

3. Yang paling memberikan pengaruh terhadap tingkat kesadaran moral karyawan ini adalah pelaksanaan aturan dan hukum yang tegas dan profesionalitas pelaksanaan pekerjaan. Oleh sebab itu pelaksanaan aturan dan prosedur yang dilakukan secara konsisten sangat efektif membangun kesadaran moral karyawan. Kerja tim yang baik akan menumbuhkan suasana keakraban yang disertai dengan suasana kerja yang jelas dan tegas aturannya merupakan hal yang penting menumbuhkan kesadaran moral karyawan KBPR TRIBAKTI ini. Dibutuhkan kepemimpinan yang sekaligus berorientasi tugas dan berorientasi pada hubungan kerja sama, yang menjalankan kepemimpinannya secara etikal, sehingga dapat menjadi panutan, pemimpin yang tegas, konsisten serta mampu membangun kebersamaan.

\section{Daftar Referensi}

Blum, L. (1991). Moral Perception and Particularity. Cambridge: Cambridge University.

Brandt, R. B. (1995). Morality, Utilitarianism, and Rights. Cambridge: Cambridge University Press.

Cullen, J.B., Victor, B., and Stephens, C.U. (1989). An Ethical Weather Report: Assessing the Organization's Ethical Climate. Organizational Dynamics. Vol. 18, Iss. 2; p. 50-52.

Fisher, C., Alan Lovell. (2003). Business Ethics and Valves, Harlow : Prentice Hall.

Rachels, J., (1989). The Right Things To Do . New York: McGraw-Hill. , (1999). The Elements of Moral Philosophy. Boston: McGraw-Hill College.

Rest, J.R. (1994). Moral Development in the Professions. Hillsdale. NJ: Lawrence Erlbaum Associate, Publishers.

Solomon, R.C. (1992). Ethics and Excellence. New York: Oxford University Press. 
Steers, Richard M. (1985). Efektifitas Organisasi (Kaidah Perilaku), Cetakan Kedua, Jakarta: Penerbit Erlangga.

Sulasmi, S. (2003). Kontribusi Perilaku Kelompok, Karakteristik Anggota Kelompok dan Kepemimpinan Pada Usaha Untuk Membangun Kualitas Sinergi, Disertasi, Institut Teknologi Bandung, tidak diterbitkan.

------- (2008). Pengaruh Kepemimpinan Membangun Semangat Kerjasama Dengan Kebersamaan Visi Sebagai Variabel Moderator. Majalah Ekonomi, Tahun XVIII No 1. April. Hal. : 35-53.

VanSandt, Craig V., 2001. An Examination of The Relationship Between Ethical Work Climate And Moral Awareness, Dissertation submitted to the Faculty of the Virginia Polytechnic Institute and State University in partial fulfillment of the requirements for the degree of Doctor of Philosophy in Management, Blacksburg: Virginia.

VanSandt, Craig V, Jon M. Shepard and Stephen M. Zappe. (2006). An Examination of The Relationship Between Ethical Work Climate and Moral Awareness. Journal of Business Ethics $68: 409-432$.

Victor, B., and Cullen, J.B., (1988). The Organization Bases of Ethical Work Climate. Administrative Science Quarterly, March Vol. 33 Iss. 1.

Weber, J. (1995). Influences Upon Organizational Ethical Subclimate: A Multidepartmental Analysis of a Single Firm. Organization Science. Sep/Oct . Vol. 6, Iss. 5.

Wimbush, J.C., and Shepard, J.M. (1994). Toward an Understanding of Ethical Climate: Its Relationship to Ethical Behavior and Supervisory Influence. Journal of Business Ethics. Aug 1994. Vol. 13, Iss. 8; p. 637-647.

\footnotetext{
* Siti Sulasmi adalah Pengajar Fakultas Ekonomi Universitas Airlangga. Kritik dan dan saran dapat langsung menghubungi penulis dengan alamat email sulasmi m@yahoo.com
} 